\title{
Roles of Micro and Small Enterprises of Snack and Pastry Productions and Product Innovation on the Increase of People's Income in Periuk - Tangerang City
}

\author{
Heri Satrianto ${ }^{1)}$ \\ heri.satrianto@ubd.ac.id \\ Suhendar Janamarta ${ }^{2}$ \\ suhendar.janamarta@ubd.ac.id \\ Sutrisna $^{3)}$ \\ sutrisna.sutrisna@ubd.ac.id
}

1) 2) 3) Management Study Program, Universitas Buddhi Dharma, Banten, Indonesia

\begin{abstract}
This research was conducted based on researchers' will to find out the Roles of Small and Micro Enterprises of Snack and Pastry Productions, and Product Inovation toward the Increase of Economy Income of Periuk People - Tangerang City.

There are many factors influencing the increase of economy income of UMKM People. Some of them are the lack of policy program on foster father, which was identified to affect the increase of people's economy income. There was also a shift on the business pattern, which is from conventional into digital. This was why the number of enterpreneurs of micro and small enterprises grew so rapid and massive that it affected the increase of people's economy income. The lack information on UMKM programs for the people was identified to affect the increase of people's economy income. The small number of innovation on snack products produced was suspected to influence the increase of people's economy income.

The independent factors studied were the Roles of Small and Micro Enterprises (X1) and Product Innovation (X2), and the dependent factor was People's Income (Y). Based on the results of correlation coefficient analysis, it was found out that coefficient correlation for X1 is 0.750 and for $\mathrm{X} 2$ was 0,805 . This means that the roles of micro and small enterprises and product innovation strongly influenced the people's income. The positive impact showed that the better the roles of micro and small enterprises and product innovation, the higher the people's income.

To find out how much they influenced, Simple Linear Regression was used as analysis tool. It was found out that the results of Variable (X1) and the value of $t_{\text {count }}$ (8.253) was higher than $\mathrm{t}_{\text {table }}$ (1.984) and it rejected Ho. So, the hypothesis is Ho was rejected and Ha was accepted. This showed that there were significant influences between roles of micro and small enterprises and the product innovation with the people's income. The variable X2 with the value of $\mathrm{T}_{\text {count }}$ 4.862 was higher than $\mathrm{T}_{\text {table }}$ and it belonged to the rejection scope of Ho. So, the hypothesis was Ho was rejected and $\mathrm{Ha}$ was accepted. This indicated that there were significant influences between product innovation and people's income.
\end{abstract}

Keyword: Roles of Micro and Small Enterprises, Product Innovation, and Income 


\section{INTRODUCTION}

There are some factors affecting a country's economy. In Indonesia, there is one sector that greatly contributes to national economy. This sector is mostly known as micro and small enterprises. Micro and small enterprises include many fields. Even though they are in small scale, they play great role in the money circulation in Indonesia. Micro enterprises are productive businesses that belong to individuals and/or organizations which meet the requirements for micro enterprises. These requirements are regulated by government in the law.

Besides above criteria, there are things that can help to identify a micro business, especially viewed from its growth. They are classified into two:

1. Livelihood: micro enterprise business whose characteristics and aims are only to make a living.

2. Micro: a micro enterprise which is developing. However, this enterprise has not either employed subcontract-workers or exported the products.

Small, micro, and medium enterprises (UMKM) have important roles on economy for Indonesians. Indonesia Government also views their significant existence of these entrepreneurs. This can be seen clearly that Cooperative-SME Ministry has specific division for UMKM and Cooperatives.

There are at least 3 important roles of UMKM in the lives of low class people. They are:

1. As the means to alleviate poverty

The very first role of UMKM is as the means to get the common people out of poverty. That UMKM absorbs high number of employees is the main reason for this. This is proven by the data of Ministry of Cooperatives and SMEs of 2011. It is mentioned that there were more than 55.2 million units of UMKM which absorbed about 101.7 million workers. This later increased to be 57.8 units of UMKM with almost 114 million workers.

2. As the means to equalize the economy level of common people

As the means to equalize the economy level of common people, UMKM also has a significant role to equalize the people's economy. UMKM is different from big companies because they spread everywhere, including the very remote areas which do not follow the world's progress. The existence of UMKM in 34 provinces of Indonesia has minimized the economy gaps between the rich and the poor. Still, people do not necessarily urbanize just to improve their living.

3. As the means for the nation's source of foreign exchange

The next role of UMKM, which is also as important as the two others, is as the source of national foreign currency. Nowadays, UMKM has been developed in Indonesia. Their market shares are not only national, but also international. Data of Ministry of Cooperatives and SMEs in 2017 showed that UMKM actors contributed to the high number of national foreign currency. It reached 88.45 billion IDR. This was eight times more than in 2016.

Within these three roles, it is not wrong if we should not underestimate the UMKM actors.

Business of snacks, which can be operated within small capital and in home-scale, has a very good opportunity not only for now but also for the future. The market's demand for snacks always flows because its lover is not only children, but also teens, adults, and parents. So, this is not surprising when the business actors of snacks are flooded with orders as their products served as the intermezzo snacks in every event.

Moreover, there is a great variety of snacks range from fruit chips, vegetable chips, cassava chips, rengginang (thick rice cracker), to baby nile tilapia crackers. They are sold at 
various prices. These open bigger opportunities for anybody who wants to start this snack business.

The snacks, that are going to be sold, should have good quality in terms of materials used, processing, and packing. The materials used should be hygienic and free from dangerous contents. The processing should follow the regulations, for example using the low temperature when frying, changing the cooking periodically. Then when packing, we should pack the fried snacks into good, interesting, and standardized packaging according to its brand.

The actors of snack enterprises are businessmen who are highly motivated to create different and new snacks. Their different and new snacks cause the consumers can easily find out and distinguish their products. So, it does not matter if their products have existed in the market as long as they are innovatively different.

The innovation can involve the product, technology in frying process (for examples vacuum frying or low-temperature frying), and packing. These can attract customers and innovation in marketing by online media. We can see nowadays many snack entrepreneurs gain their success because of their innovations.

Great care is given to the actors of UMKM. This is just to show how Government supports the middle class people's economy.

The snacks, that are going to be sold, should have good quality in terms of materials used, processing, and packing. The materials used should be hygienic and free from dangerous contents. The the processing should follow the regulations, for example using the low temperature when frying, changing the cooking periodically. Then when packing, we should pack the fried snacks into good, interesting, and standardized packaging according to its brand.

The actors of snack enterprises are businessmen who are highly motivated to create different and new snacks. Their different and new snacks cause the consumers can easily find out and distinguish their products. So, it does not matter if their products have existed in the market as long as they are innovatively different.

The innovaton can involve the product, technology in frying process (for examples vacuum frying or low-temperature frying), and packing. These can attract customers and innovation in marketing by online media. We can see nowadays many snack entrepreneurs gain their success because of their innovations.

\section{FINDINGS AND DISCUSSION}

\section{Respondents' Profiles}

Kecamatan Periuk (Periuk Subdistrict) is one of 13 Subdistricts in Tangerang City. Geographically, it has borders; the north with Neglasari Subdistric, the south with Jatiuwung Subdistrict, the east with Karawaci Subdistrict, and the West with Tangerang Regency.

In 2018, there were 45,236 households and 148,829 people in Periuk Subdistrict. The people are 76,094 males and 72,735 females. These figures show that the male population is higher than the female.

From the age productivity, the people in Periuk Subdistrict are divided into three. The productive age belong to people of 15-64 years old. There were 108,414 people belong to this category. Meanwhile, the non-productive age belong to people of 0-14 and 65-74 years old. There were 40,516 people belong to this group.

In Periuk Regency, there is Community of UMKM Periuk (CUP) Bestari. This organization is expected to be the forum for UMKM actors in Periuk for sharing information and 
for gathering. CUP Bestari is expected to be able to introduce various products of Periuk's UMKM; traditional market snacks, pastries, etc and to participate in various event in subdistrict or city level.

\section{Validity Test}

In this research, the researchers created 10 questions for every variable. There were 100 respondents for data collections. Within the significance level $5 \%$, it was found out that $\mathrm{R}_{\text {table }}$ value is 0.195 . This value or $R_{\text {table }}$ was later compared with $R_{\text {count }}$ gained from SPSS output. Table 2 showed that all $R_{\text {count }}$ values were higher than $R_{\text {table }}$ values. So, it can be concluded that all the items in the questionnaire were valid.

Table 1

Results of Validity Test

\begin{tabular}{|l|r|r|c|}
\hline Code & R Count & R Table & Description \\
\hline X11 & .725 & .195 & Valid \\
X12 & .723 & .195 & Valid \\
X13 & .739 & .195 & Valid \\
X14 & .721 & .195 & Valid \\
X15 & .736 & .195 & Valid \\
X16 & .710 & .195 & Valid \\
X17 & .757 & .195 & Valid \\
X18 & .713 & .195 & Valid \\
X19 & .725 & .195 & Valid \\
X110 & .738 & .195 & Valid \\
\hline X21 & .782 & .195 & Valid \\
X22 & .773 & .195 & Valid \\
X23 & .765 & .195 & Valid \\
X24 & .784 & .195 & Valid \\
X25 & .765 & .195 & Valid \\
X26 & .786 & .195 & Valid \\
X27 & .771 & .195 & Valid \\
X28 & .771 & .195 & Valid \\
X29 & .768 & .195 & Valid \\
X210 & .773 & .195 & Valid \\
\hline Y1 & .747 & .195 & Valid \\
Y2 & .789 & .195 & Valid \\
Y3 & .773 & .195 & Valid \\
Y4 & .747 & .195 & Valid \\
Y5 & .762 & .195 & Valid \\
Y6 & .774 & .195 & Valid \\
Y7 & .763 & .195 & Valid \\
Y8 & .747 & .195 & Valid \\
Y9 & .788 & .195 & Valid \\
Y10 & .788 & .195 & Valid \\
\hline
\end{tabular}

\section{Reliability Test}

The reliability leves of variables were scored from Alpha Cronbach value. Results of reliability measurement as shown in Table 3 showed that the values of Alpha Cronbach for all the variables were more than 0.7 (Stanislaus Uyanto, 2009). So, it can be concluded that all the instruments set on the variables were already reliable. 
Table 2

Results of Validity Test

\begin{tabular}{|c|c|c|}
\hline Variable & $\begin{array}{c}\text { Alpha } \\
\text { Cronbach }\end{array}$ & Description \\
\hline $\mathrm{X} 1$ & .749 & Reliabel \\
\hline $\mathrm{X} 2$ & .792 & Reliabel \\
\hline $\mathrm{Y}$ & .787 & Reliabel \\
\hline
\end{tabular}

\section{Discussions}

To find out whether there were influences or not between variables X1 and X2 and to measure the strength of the influences, multiple linear regression analysis was used by SPSS (Statistical Package for Service Softition) calculation. The results are as following:

Table 3

Multiple Linear Regression Test

\begin{tabular}{|c|c|c|c|c|c|c|c|c|c|}
\hline & \multirow{2}{*}{ Model } & \multicolumn{2}{|c|}{$\begin{array}{l}\text { Unstandardized } \\
\text { Coefficients }\end{array}$} & \multirow{2}{*}{$\begin{array}{c}\begin{array}{c}\text { Standardize } \\
\text { d } \\
\text { Coefficients }\end{array} \\
\text { Beta }\end{array}$} & \multirow{2}{*}{$\mathbf{T}$} & \multirow{2}{*}{ Sig. } & \multicolumn{3}{|c|}{ Correlations } \\
\hline & & B & Std. Error & & & & $\begin{array}{l}\text { Zero- } \\
\text { order }\end{array}$ & Partial & Part \\
\hline \multirow[t]{2}{*}{1} & (Constant) & 14.548 & 2.634 & & 5.523 & .000 & & & \\
\hline & $\begin{array}{l}\text { Roles of Micro and Small } \\
\text { Enterprises }\end{array}$ & .684 & .061 & .750 & 11.234 & .000 & .750 & .750 & .750 \\
\hline \multirow[t]{3}{*}{2} & (Constant) & 5.888 & 2.968 & & 1.984 & .050 & & & \\
\hline & $\begin{array}{l}\text { Roles of Micro and Small } \\
\text { Enterprises }\end{array}$ & .526 & .064 & .577 & 8.253 & .000 & .750 & .642 & .497 \\
\hline & Product Innovation & .358 & .074 & .340 & 4.862 & .000 & .634 & .443 & .293 \\
\hline
\end{tabular}

a. Dependent Variable: y

In $t$ column, $T$ test was used. To test validity of the hypothesis, $\mathrm{T}_{\text {count }}$ scores gained were

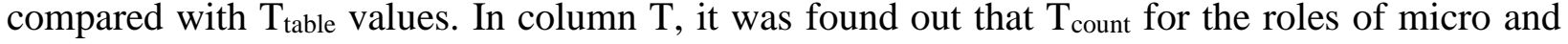
small enterprises was 8.253 . By using T normal distribution table and certainty level $(1-\alpha) 95 \%$ and test margin of error $(\alpha) n-2=100-2=98$, it was found out that distribution value of $T_{\text {table }}$ was 1.984. Because $\mathrm{T}_{\text {count }}$ of roles of micro and small enterprises was higher than peran dari $\mathrm{T}_{\text {table }}$ or 8,253 > 1,984, Ho was rejected and Ha was accepted. Meanwhile the column of $\mathrm{T}_{\text {count }}$ for Product Innovation $\left(\mathrm{X}_{2}\right)$ was 4,862 by using $\mathrm{T}$ normal distribution table, margin of error $(\alpha) 5 \%$, and degree of freedom or (df) $n-2=100-2=98$, so the $T_{\text {table }}$ distribution value gained was 1.984. Since $\mathrm{T}_{\text {count }}$ of product innovation was higher than $\mathrm{T}_{\text {table }}$ or $4.862>1.984$, Ho was rejected and Ha was accepted. 
Table 4

Regression Models

\begin{tabular}{|c|c|c|c|c|c|c|c|c|c|}
\hline \multirow[b]{2}{*}{ Model } & \multirow[b]{2}{*}{ R } & \multirow[b]{2}{*}{$\begin{array}{c}\mathrm{R} \\
\text { Square }\end{array}$} & \multirow[b]{2}{*}{$\begin{array}{l}\text { Adjusted } \\
\text { R Square }\end{array}$} & \multirow[b]{2}{*}{$\begin{array}{l}\text { Std. Error } \\
\text { of the } \\
\text { Estimate }\end{array}$} & \multicolumn{5}{|c|}{ Change Statistics } \\
\hline & & & & & \begin{tabular}{|c|}
$\mathrm{R}$ \\
Square \\
Change \\
\end{tabular} & $\begin{array}{c}F \\
\text { Change }\end{array}$ & $d f 1$ & df2 & $\begin{array}{l}\text { Sig. F } \\
\text { Change }\end{array}$ \\
\hline 1 & $.750^{\mathrm{a}}$ & .563 & .558 & 2.07648 & .563 & 126.212 & 1 & 98 & .000 \\
\hline 2 & $.805^{\mathrm{b}}$ & .649 & .641 & 1.87150 & .086 & 23.644 & 1 & 97 & .000 \\
\hline
\end{tabular}

a. Predictors: (Constant), $X_{1}$

b. Predictors: (Constant), $\mathrm{X}_{1}, \mathrm{X}_{2}$

The column of $\mathrm{R}$ square for model 1 showed that $\mathrm{R}$ square was 0.653 (which is the squaring for correlation coefficient of $0.750 \times 0.750=0.563)$. $\mathrm{R}$ Square is also named as coefficient of determination. This means that the influence of roles of micro and small enterprises on people's income was 56.3\%. Meanwhile, the rest $(100 \%-56,3 \%=43,7 \%)$ was influenced by other factors. $\mathrm{R}$ Square ranged from 0 to 1 . The less the $\mathrm{R}$ Square value, the stronger the relation between variables and vice versa it showed. The R Square for model 2 showed the R Square was 0.649 (which is the squaring of correlation coefficient or $0.805 \times 0.805$ $=0.649$ ). $\mathrm{R}$ Square was also called coefficient of determination. This means that the influence of of product innovation on the people's income was $64 \%$, and the rests was influenced by other factors. R Square ranged from 0 to 1 , the less the $\mathrm{R}$ Square the stronger the relation between variables it showed, and vice versa.

\section{CONCLUSION}

From the previous analyses and the discussions, we can take some conclusions on roles of micro and small enterprises of snacks, pastries, and product innovation toward the increase of people's economy income in Periuk Subdistrict - Tangerang City. Here they are:

1. People's income was really affected by the roles of micro and small enterprises and product innovation. Thus, people of Periuk Subdistrict - Tangerang City were expected to sustain the existing micro and small enterprises and product innovation. They can do this by taking training, joining the exhibitions conducted by UMKM, and controlling the production and packaging process to minimize error and to maximize their income. This, in the end, was going to improve people's economy.

2. The economy income of Periuk Subdistrict people could be said to increase. These could be confirmed by the respondents' answers on 10 questions on eoncomy income of people of Periuk Subdistrict. The level of people's income was influenced by the roles of micro and small enterprises and product innovation. If their roles can be maximized, the people's income can be increase.

3. From the results of $\mathrm{X} 1$ and $\mathrm{X} 2$ toward $\mathrm{Y}$, by using analysis on correlation coefficient, it was found out that correlation coefficient for $\mathrm{X} 1$ was 0.750 . This means that the roles of micro and small enterprises strongly influenced people's income. Then, X2 showed correlation coefficient for 0.805 . This means that product innovation strongly influenced people's income. The positive influences showed that the better the roles of micro and small enterprises and product innovation, the higher the people's income was. 
4. Variable X1 with the value of Tcount 8.253 was higher than the value of Ttable 1.984. So, the hypothesis Ho was rejected and $\mathrm{Ha}$ was accepted. This showed there was a significant influence between the roles of micro and small enterprises and people's income.

5. Variable X2 with the value of Tcount 4.682 was higher than the value of Ttable 1.984. So, the hypothesis Ho was rejected and Ha was accepted. This showed that there was a significant influence between product innovation and people's income.

6. Research Results of Regression Equation showed that $\mathrm{Y}=5,888+0,526 \mathrm{X}_{1}+0,358 \mathrm{X}_{2}$, which means for every 1 point of increase or decrease of roles of the small and micro enterprises, people's income would increase or decrease for 0.526 . Meanwhile, for every 1 point increase or decrease on product innovation, people's income would increase or decrease for 0.358 .

Significant influences meant that the increase on the roles of micro and small enterprises and product innovation could increase the people's income. On the contrary, the decrease on the roles of micro and small enterprises and product innovation could decrease the people's income.

\section{DAFTAR PUSTAKA}

Atsarina Luthfiyyah, 2019 Resep Keripik Singkong, Bidang Tataboga, Ilmu Komunikasi Universitas Gadjah Mada

Endang Harningsih dan Rintar Agus Harilintar, Faktor - faktor Yang Mempengaruhi Kinerja Usaha Pedagang Eceran Jurnal : jpmanajemen dd080093

Harhayadi, 2011, Citarasa makanan ringan. berbeda-beda, ada yang manis, asin, gurih, dan bahkan pedas. Snack Food.

Ina Primiana, Prof. Dr., S.e., M.t.,2003 - 2009, Menggerakan Sektor Riil UMKM\& Industri dalam Sektor Ekonomi, Alfabeta

Kanaidi, SE, M.Si, 2010, Koperasi dan UMKM, (Koperasi Usaha Mikro Kecil dan Menengah), Manajemen Bisnis Politeknik Pos Indonesia, Bandung.

Munandar, 2006, Teori Pendapatan Ekonomi,

M. Kwartono, 2009, Kiat Sukses Berburu Modal UMKM , Raih Asa Sukses, Jakarta

Nuran Wibisono, 2016, Olahan Daging dalam Jagat Kuliner Dunia, Gaya Hidup tirto.id

Rudjito. 2003. Strategi Pengembangan Umkm Berbasis Strategi Bisnis, Makalah Study Kasus Bank BRI

Sukirno, 2000, Teori Pendapatan Ekonomi, 